\title{
Color Stability of Composites Subjected to Accelerated Aging after Curing Using Either a Halogen or a Light Emitting Diode Source
}

\author{
Fernanda de Carvalho Panzeri PIRES-DE-SOUZA ${ }^{1}$ \\ Lucas da Fonseca Roberti GARCIA ${ }^{1}$ \\ Hisham Mohamad HAMIDA ${ }^{1}$ \\ Luciana Assirati CASEMIRO ${ }^{1,2}$ \\ ${ }^{1}$ School of Dentistry of Ribeirão Preto, University of São Paulo, Ribeirão Preto, SP, Brazil \\ ${ }^{2}$ School of Dentistry, University of Franca, Franca, SP, Brazil
}

\begin{abstract}
The purpose of this study was to evaluate, in vitro, the color stability of three composite resins of two different shades (A3 and C3) cured with either a quartz tungsten halogen (QTH) or a light emitting diode (LED) source. Forty specimens (20 x 2 mm) were prepared for each composite (Tetric Ceram ${ }^{\circledR}$, Heliomolar ${ }^{\circledR}$ and Esthet- $X^{\circledR}$ ), being 20 for each shade. In each group, 10 specimens were light-cured using the QTH unit and 10 with the LED source. The shade of the materials was evaluated before and after submitting the specimens to artificial accelerated aging ( $4 \mathrm{~h} \mathrm{UV-B} / 4 \mathrm{~h}$ condensing vapor), using a reflection spectrophotometer. $\Delta \mathrm{E}$ means were calculated and analyzed statistically by 2-way ANOVA and Tukey's test at 5\% significance level. Both A3 and C3 shades of Esthet-X composite resin showed the lowest color change when cured with the QTH light, while Tetric C3 cured with the QTH light showed the highest color change.
\end{abstract}

Key Words: composites, color stability, quartz tungsten halogen light, light emitting diode.

\section{INTRODUCTION}

Esthetic failure is one of the most common reasons for the replacement of restorations. A good combination of the tooth color and the initial color of the material before curing is an important clinical factor for a clinically successful outcome. Nonetheless, this combination must remain after the material is completely cured and throughout the restoration life-time. If the color of the composite changes with time, its main advantage, esthetics, is lost. For this reason, studies have been performed with the goal of assessing the maximum color stability of composites through time $(1,2)$.

There are many factors linked to the discoloration of materials in the oral environment (3). The structure of the composite and the characteristics of the particles have direct effects on surface polishing and on the susceptibility to extrinsic staining (4). Restoration polishing is particularly important in order to delay the discoloration and aging processes of the composite. Higher smoothness and less porosity reduce the adherence of agents responsible for changing the color of composites, such as dental biofilm, food colorants, tobacco, and others (5). The use of mouthrinses, such as chlorhexidine, does not show a high importance on color stability $(4,6)$. Composite resins have a variety of organic components that may cause intrinsic discoloration. A discoloration of the deep layers of the composite may occur due to physicochemical reactions of the material itself, such as those that occur with tertiary amines and may cause composites to become yellowish. Self-curing composites show a higher discoloration than light-cured ones (7), which suggests that the

Correspondence Profa. Dra. Fernanda de Carvalho Panzeri Pires-de-Souza, Departamento de Materiais Dentários e Prótese, Faculdade de Odontologia de Ribeirão Preto - USP, Avenida do Café, s/nº - Monte Alegre, 14040-904 Ribeirão Preto, SP, Brasil. Tel: +55-16-36024081. Fax: +55-16-3917-3384. e-mail: ferpanzeri@forp.usp.br 
degree of conversion plays an essential role in the color stability of these materials (8).

There are currently many composite colors available to professionals who intend to place esthetic restoration. There are very light colored composites, almost transparent, and others that reach brown tones. Each composite tone behaves differently to light-curing because darker colors require higher light intensity for the conversion of monomers (9).

Quartz tungsten halogen (QTH) lights and light emitting diodes (LEDs) are the currently used light sources for curing composites. QTH light is produced by an electrical current that flows through a fine tungsten filament. This filament functions as a resistor and the heat of the current is so strong that it emits electromagnetic radiation in the form of visible light. About the LEDs, this system, opposed to QTH light, does not produce visible light through the heating of metal filaments, but through mechanical-quantical effects. LEDs are basically a combination of two different semiconductors ('n-doped' and 'p-doped'). The ndoped semiconductor has an excess of electrons and the p-doped has a need for electrons. When both semiconductors are combined and a certain voltage is applied, the n-doped and p-doped conductors connect. The result is a characteristic light with a specific wave length (10). This brings interest to the study of the influence of these two types of curing systems on the color stability of restorative materials.

The purpose of this study was to evaluate, in vitro, the color stability of three composite resins of two different shades (A3 and C3) cured with either a QTH or a LED source.

\section{MATERIAL AND METHODS}

Three direct composites (Table 1) of two different shades were used: one light (A3) and one dark (C3). A metallic matrix ( $20 \times 2 \mathrm{~mm}$ ) was used for fabrication of the specimens $(\mathrm{n}=10)$. Forty specimens were prepared per restorative material. The composites were inserted into the matrix cavity incrementally (2-mmthick increments) and each increment was cured using either a QTH lamp (Ultralux; Dabi Atlante, Ribeirão Preto, SP, Brazil; $\cong 500 \mathrm{~mW} / \mathrm{cm}^{2}$ ) or a LED source (Ultraled; Dabi Atlante; $\cong 320 \mathrm{~mW} / \mathrm{cm}^{2}$ ), for the time recommended by the manufacturers. With the cavity filled, a polyester strip was placed onto the composite in order to increase surface smoothness and facilitate polishing subsequently. A glass plate ( 40 x 40 x 2 mm) was placed over the polyester strip and pressure was applied until the plate touched the matrix completely, thus allowing excess composite to flow prior to curing of the last increment.

As the QTH light beam covered the specimen completely, polymerization was performed twice with this unit. The LED source, however, was approximately $1 / 4$ the specimen size. Therefore, for polymerization with the LED unit, the specimen was divided into four quadrants. Each quadrant was polymerized twice; one

Table 1. Materials appraised and their characteristics.

\begin{tabular}{|c|c|c|c|}
\hline Composite & Manufacturer & Particle size & Composition \\
\hline $\begin{array}{c}\text { Esthet-X }^{\circledR} \\
\text { (Micro hybrid) }\end{array}$ & $\begin{array}{l}\text { Dentsply Ind. e } \\
\text { Com. Ltda., } \\
\text { Petrópolis, RJ, Brazil }\end{array}$ & $0.04-1.0 \mathrm{~mm}$ & $\begin{array}{c}\text { Bis-GMA, Bis-EMA, } \\
\text { TEGDMA, barium fluoro } \\
\text { alumino boro silicate glass, } \\
\text { camphorquinone, stabilizer and pigments }\end{array}$ \\
\hline $\begin{array}{c}\text { Tetric Ceram }^{\circledR} \\
\text { (Hybrid) }\end{array}$ & $\begin{array}{l}\text { Ivoclar Vivadent, } \\
\text { Schaan, } \\
\text { Liechtenstein }\end{array}$ & $0.04-3.0 \mathrm{~mm}$ & $\begin{array}{l}\text { Bis-GMA, UDMA, TEGDMA, } \\
\text { ytterbiumtrifluoride, initiators, } \\
\text { stabilizers and pigments }\end{array}$ \\
\hline $\begin{array}{c}\text { Heliomolar }^{\circledR} \\
\text { (Microparticle) }\end{array}$ & $\begin{array}{l}\text { Ivoclar Vivadent, } \\
\text { Schaan, } \\
\text { Liechtenstein }\end{array}$ & $0.04-0.2 \mathrm{~mm}$ & $\begin{array}{l}\text { Bis-GMA, UDMA, silicondioxide, } \\
\text { ytterbiumtrifluoride, catalysts, } \\
\text { stabilizers and pigments }\end{array}$ \\
\hline
\end{tabular}


time with the glass plate and another without it.

After matrix removal, the specimens were stored in light-proof dark plastic receptacles and thereafter polished with Sof-Lex disks (3M do Brazil, Sumaré, SP, Brazil) in a sequence of decreasing abrasiveness. The polished specimens had their thickness measured with an electronic digital pachymeter accurate to $0.1 \mathrm{~mm}$ (Digimess, São Paulo, SP, Brazil). Next, a mark was made on the specimen to ensure that color reading would be done always at the same spot.

The color of the specimens was analyzed with a portable reflection spectrophotometer (Color Guide 45/ 0, BYK-Gardner GmbH, Geretsried, Germany) employing an optical geometry $45^{\circ} / 0^{\circ}$. Color was evaluated according to the color system CIE-L*a*b* (11), in which $\mathrm{L}$ indicates color luminosity (ranging from 0 black to 100 - white); $a^{*}$ determines the amount of red (positive values) and green (negative values); $\mathrm{b} *$ determines the amount of yellow (positive values) and blue (negative values).

After color readings, the specimens were subjected to an accelerated aging system (C-UV, Adexim Comexim, São Paulo, SP, Brazil). The specimens were placed on the equipment's fixing plates and taken to the condensation chamber facing the light source, at a distance of $50 \mathrm{~mm}$, for $4 \mathrm{~h}$ (ASTM standard) (12).

After the aging process, the specimens were resubmitted to color analysis with the spectrophotometer, and from the differences of the values of $\mathrm{L}^{*}, \mathrm{a}^{*}$, and $\mathrm{b}^{*}$ it was possible to find the colorimetric values $\Delta \mathrm{L}^{*}, \Delta \mathrm{a}^{*}$, and $\Delta \mathrm{b}^{*}$. The differences of color were given by $\Delta E^{*}$, which was obtained using the following equation (11): $\sqrt{\Delta E^{*}=\left(\Delta L^{*}\right)^{2}+\left(\Delta a^{*}\right)^{2}+\left(\Delta B^{*}\right)^{2}}$.

For each material, the $\Delta \mathrm{E}$ means were subjected to statistical analysis by 2-way ANOVA and Tukey's test with level of significance of 5\%. The means were compared in terms of the tested composite shades and source of curing.

\section{RESULTS AND DISCUSSION}

Results are shown on Table 2. Analyzing the composite shade A3, there was no statistically significant difference between the $\Delta \mathrm{E}$, independent of the curing device. Nonetheless, comparing the results of composite shade $\mathrm{C} 3$, the $\Delta \mathrm{E}$ of the Tetric composite was statistically different $(\mathrm{p}<0.01)$ when cured by the different light sources (Table 2).

Subsequently, fixing the curing method as the comparison factor, it was verified that Tetric C3 showed a higher variation of $\Delta \mathrm{E}$ in terms of shade $\mathrm{A} 3$, when using the QTH light source as well as the LED light source $(\mathrm{p}<0.001)$.

Comparing the different types of resins in relation to shade A3, Heliomolar showed a higher color variation than the other composites when cured with LED light, with statistically different values $(\mathrm{p}<0.001)$. In relation to shade $\mathrm{C} 3$, the data were more heterogeneous. Esthet-X showed the highest color variation, cured with QTH light as well as with LED, with statistically significant values for the other tested composites. Following Esthet-X, the composite that showed highest variation was Heliomolar. When cured with QTH light, it showed statistically significant values in relation to the other tested composites. When cured with LED, it showed statistically significant differences only in relation to Esthet-X (Table 2).

The color changes among brands, cured with

Table 2. $\Delta \mathrm{E}$ obtained for the composite resin specimens cured with the QTH or LED source after artificial accelerated aging.

\begin{tabular}{|c|c|c|c|c|c|c|}
\hline \multirow[t]{2}{*}{ Cure } & \multicolumn{2}{|c|}{ Esthet-x } & \multicolumn{2}{|c|}{ Tetric Ceram } & \multicolumn{2}{|c|}{ Heliomolar } \\
\hline & A3 & C3 & A3 & C3 & A3 & C3 \\
\hline QTH & $2.738 \pm 0.621 \mathrm{aA}$ & $2.897 \pm 0.740 \mathrm{aC}$ & $3.634 \pm 1.452 \mathrm{aAB}$ & $9.781 \pm 1.212 \mathrm{bA}$ & $5.199 \pm 1.016 \mathrm{aB}$ & $6.136 \pm 0.521 \mathrm{aB}$ \\
\hline LED & $2.419 \pm 0.487 \mathrm{aA}$ & $4.086 \pm 0.757 \mathrm{aB}$ & $2.57 \pm 1.711 \mathrm{aA}$ & $7.356 \pm 2.563 \mathrm{cA}$ & $5.474 \pm 0.966 \mathrm{aB}$ & $6.106 \pm 0.935 \mathrm{aA}$ \\
\hline
\end{tabular}

Different lowercase letters in columns and uppercase letters in lines indicate statistically significant difference at $5 \%$ significance level (Tukey's test). 
the same lights, were also compared. In relation to the QTH light-curing method, Esthet-X showed the lowest color variation for both shades A3 and C3. Values were statistically significant only for C3. For A3 composites, the means were statistically different only for Heliomolar. The composite Tetric showed intermediary values of color change, but they were not significant in relation to the other composites.

In relation to the LED curing method, for shade A3 the composite Heliomolar showed the highest $\Delta \mathrm{E}$ values, statistically different from the other two materials, which did not differ significantly to each other (Fig. 1). For shade C3, the lowest changes occurred, once again, for Esthet-X, with statistically significant values in relation to the other composites, which did not differ significantly to each other.

Several authors consider 3.3 a critical value for $\Delta \mathrm{E}$, considering it as clinically unacceptable because, at this value, color modification becomes perceptible to the human eye $(13,14)$. In our study, only Esthet-X maintained the $\Delta \mathrm{E}$ within clinically accepted values, except for shade C3 cured with LED light ( $\Delta \mathrm{E}=4.086$ ). The other composites, for both shades A3 and C3, showed $\Delta \mathrm{E}>3$, that is, with perceptible color modifications, with the exception of composite Tetric A3 cured with LED light, which showed $\Delta \mathrm{E}=2.57$.

Manufacturers and researchers are concerned with the light source used to convert the composite, and are investigating whether there is a correlation between the intensity of light source, time of exposure, types of material, and distance from the tooth to the curing source (15). This concern is due to the fact that, although used in small amounts (0.03-0.1\% in mass), camphoroquinone significantly influences the color of the material (16) as it is a yellow chemical compound. During light irradiation at 478nm wavelength, it changes color and becomes colorless. However, if irradiation is not enough, a certain amount of yellow will remain. Hence, under the influence of the environment's light, an additional conversion of camphoroquinone will take place, although the composite has already been cured, making the restoration clearer (9), which can be numerically translated into an increase in $L^{*}$ value. In the present study, L had its value increased for Tetric composite after being subjected to accelerated aging.

This can be avoided only if a good level of conversion is obtained with the correct use of the light source, determined by the number of double carbon bonds that are converted into simple bonds (17). This level of conversion depends, among other factors, on the composition of the material (18). As light passes through the composite, it is absorbed and spread out, reducing the intensity and diminishing the effectiveness of light used for curing as the depth increases. Thus, the type of filler particle and its size interfere with this level of conversion and, consequently, on the stability of the composites (19).

In the present work, 3 types of composites were used: one microhybrid, one hybrid and one microparticle. The results showed better color stability for hybrid composite, independent of the type of curing light, similar to results published elsewhere $(3,13)$.

It is acknowledged in the literature $(8,11)$ that composite resins allow water sorption in one of the most critical points of a composite, which is the interface organic matrix/filler particles. Considering that color perception is directly related to the reflection of light, the results of the present study may be explained by the hydrolytic degradation of this interface, which may change the path through which light spreads within these particles. Larger filler particles would have a degree of degradation different from that of smaller particles. Thus, the microparticle composite showed higher color changes, followed by the microhybrid composite, and lastly the hybrid composite.

Heliomolar showed yellowing after aging, numerically translated by an increase of the value of $b^{*}$. Considering that there was a complete conversion of camphoroquinone, composite yellowing may have been caused by the aliphatic amines, which are important collaborators of the photo-initiators in the curing process of the composite. It is acknowledged that amines are capable of forming by products during light-curing reaction, which tend to make the material yellowish or brownish under the influence of light (20). These colorations depend on the type and quantity of synergetic elements added to the photo-initiator. Taking this factor into consideration, Heliomolar must have a high amount of amines in relation to the other materials.

In order to confirm the theories discussed herein it would be necessary to perform comparative analytical tests of the components of each material cured with QTH light and LED sources.

Based on the results, it may be concluded that: 1 . Only Esthet-X presented color changes within the clinically acceptable levels $(\Delta \mathrm{E}<3.3)$ when QTH light 
was used; 2. As to the influence of the light-curing unit, the LED unit provided less color changes only for the hybrid composite A3, with significant values, although these values are above the critical $\Delta$ E level; 3 . Considering the shades of each type of tested composite, there was no statistically significant difference among them when cured with halogen or LED light, except for the hybrid composite, which showed less color change for composite A3, regardless of the light-curing unit.

\section{RESUMO}

O objetivo deste estudo foi verificar a estabilidade de cor de três compósitos polimerizados com dois tipos de unidades polimerizadoras, luz halógena ou diodo emissor de luz (LED). Quarenta amostras (20 mm de diâmetro por 2 mm de espessura) foram construídas com cada compósito (Tetric Ceram ${ }^{\circledR}$, Heliomolar ${ }^{\circledR}$ and Esthet- $\left.X{ }^{\circledR}\right)$, vinte na cor A3 e vinte na cor C3. Dentro de cada grupo, 10 amostras foram polimerizadas com luz halógena e as outras com LED. A cor dos materiais foi verificada antes e depois das amostras serem submetidas ao envelhecimento artificial acelerado (4h UV-B/4h de condensação de vapor), usando um espectrofotômetro de reflexão. As médias $\Delta \mathrm{E}$ de foram calculadas e analisadas estatisticamente (ANOVA a dois critérios e teste de Tukey, 95\%). Os compósitos Esthet-X A3 e C3 demonstraram a menor alteração de cor quando polimerizados com luz halógena enquanto a resina. Tetric C3 apresentou a maior alteração de cor quando polimerizada por essa mesma fonte de luz.

\section{REFERENCES}

1. Imazato S, Tarumi H, Kato S, Ebisu S. Water sorption and colour stability of composites containing the antibacterial monomer MDPB. J Dent 1999;27:279-283.

2. Abu-Bakr N, Han L, Okamoto A, Iwaru M. Color stability of compomer after immersion in various media. J Esthet Dent 2000;12:258-263.

3. Stober T, Gilde H, Lenz P. Color stability of highly filled composite resin materials for facings. Dent Mater 2001;17:87-94.

4. Lee YK, El Zawahry M, Noaman KM, Powers JM. Effect of mouthwash and accelerated aging on the color stability of esthetic restorative materials. Am J of Dent 2000;13:159161
5. Vichi A, Ferrari M, Davidson LC. Color opacity variations in the different resin-based composite products after water aging. Dent Mater 2004;20:530-534.

6. Dietschi D, Campanile G, Holz J, Meyer JM. Comparison of the color stability of ten new-generation composites: An in vitro study. Dent Mater 1994;10:353-362.

7. Robinson FG, Rueggeberg FA, Lockwood PE. Thermal stability of direct dental esthetic restorative materials at elevated temperatures. J For Sci 1998;43:1163-1167.

8. Eldiwany M, Friedl KH, Powers JM. Color stability of lightcured and post-cured composites. Am J Dent 1995;8:179181.

9. Tyas MJ. Colour stability of composite resins: A clinical comparison. Aust Dent J 1992;37:88-90.

10. Janda R, Roulet JF, Kaminsky M, Steffin G, Latta M. Color stability of resin matrix restorative materials as a function of the method of light activation. Eur J Oral Sci 2004;112:280285.

11. CIE (Commission Internationale de l'Eclairage). Colorimetry technical report. CIE Pub. $N^{\circ} 15$, 2nd ed. Vienna, Austria: Bureau Central da La CIE, 1986, [corrected reprint 1986].

12. ASTM Standards G154-00a. Standard practice for operating fluorescent light apparatus for UV exposure of nonmettalic materials. Annual Book of ASTM Standards, v. 14.04. Pennsylvania: United States; 2006:646-654.

13. Mills RW, Jandt KD, Ashworth SH. Dental composite depth of cure with halogen and blue light emitting diode technology. Brit Dent J 1999;186:388-391.

14. Schulze KA, Marshall SJ, Gansky SA, Marshall GW. Color stability and hardness in dental composites after accelerated aging. Dent Mater 2003;19:612-619.

15. Lee YK, Lim BS, Kim CW. Influence of illuminating and viewing aperture size on the color of dental resin composites. Dent Mater 2004;20:116-123.

16. Dlugokinski MD, Cauguman FW, Rueggeberg FA. Assessing the effect of extraneous light on photoactivated resin composites. J Am Dent Assoc 1998;129:1103-1109.

17. Shintani H, Yamaki M, Inque T. Analysis of camphorquinone in visible light-cured composite resins. Dent Mater 1985;1:124-126.

18. Lee SY, Greener EH. Effect of excitation energy on dentin bond strength and composite properties. J Dent 1994;22:175181.

19. Chung KH, Greener EH. Correlation between degree of conversion, filler concentration and mechanical properties of posterior composed resins. J Oral Rehabil 1990;17:487-494.

20. Braden M, Clarke RL. Water absorption characteristics of dental microfine composites filling materials. I. Proprietary materials. Biomater 1984;5:369-372.

Accepted April 10, 2007 